owners of coniferous plantations to execute moderate thinnings that will yield pit-props of useful sizes. The present time also affords an excellent opportunity for the clear-felling of unprofitable woods, that is, of all those which are not in a thriving state, or which are insufficiently stocked, or which are over-ripe, and no longer increasing in volume at an appreciable rate. A considerable area of coppice, which has been nearly worthless for some years past, owing to the constantly declining prices of all kinds of small timber, should also be cleared, and be converted into conifer plantations. All such clearances would provide a good deal of timber useful in the present crisis, which was formerly impossible to sell, owing to the abundant supply at a cheap price of the same kind of timber from the Baltic. After the trees are felled, re-planting with fast-growing conifers (as a general rule) should be proceeded with at once. All these operations, felling, planting, etc., would give rise to much employment of labour in country districts during the coming winter, and help to check the migration of the unemployed into the large cities.

Reasonable schemes of State afforestation have hitherto been regarded unfavourably by those in authority, but this view may change after the war is over. Meanwhile, during the present time of national danger, a great deal of useful work can be done by private owners of woodlands on the lines suggested above. There is little doubt that plantations, which can be made out of the proceeds of the sale of pit-timber besides increasing the employment of labour, will prove a safe investment.

What is possible in the way of afforestation in Scotland is the chief subject discussed in Transactions of the Royal Scottish Arboricultural Society (vol. xxviii., part 2), which has recently appeared. This part, besides some useful articles and notes on Douglas fir, Sitka spruce, acetone, etc., gives an account of a tour of inspection of the woods and afforestable lands of the Highlands, made during last July, to which foreign 4 and colonial representative foresters were invited. The splendid results obtained by modern methods of forestry in Perthshire, Deeside, and Strathspey were much admired. The enormous area of land suitable for afforestation was the main feature noticed in Inverness-shire and Argyllshire.

As an example of what can be done in a short period of years, the Benmore plantations on the Clyde are most remarkable. Here 2000 acres were planted thirty-four years ago, mostly on steep and rocky hill-sides, from sea-level to $\mathrm{I} 200 \mathrm{ft}$. altitude, the soil being a poor sandy peat covered with heather.

The species cultivated are mainly Douglas fir, larch, Thuya gigantea, Scots pine, and spruce; and the average volume per acre is about 3400 cubic feet, i.e., an annual yield of Ioo cubic feet of timber. One detached small plantation of

4 Dr. P. E. Müller, the great authority on Forest Soils, was the delegate from Denmark. His views concerning the succession of soils and of species of trees in the Danish forests form the subject of an article in the Transactions, p. $24 \mathrm{r}$, which is of int rest to plant ecologists as well as foresters. NO. 2354 , VOL. 94]
Douglas fir and Thuya, situated at a low level, under I30 ft. altitude, was blown down in I9I2, when it was thirty-five years old, and yielded the enormous volume of $743^{\circ}$ cubic feet of timber per acre, which was actually sold for I $30 l$. The cost of planting, loss of grazing ( $5 s$. per acre), rates, taxes, expenses of management, with compound interest at 3 per cent. added, amounted to $6 r l$. so that this plantation gave a net profit of $69 l$. per acre at the end of thirty-five years. The owner of the estate, Mr. H. G. Younger, stated that the whole glen, if afforested in the same way, which could easily be done, would support an extra rooo families by the employment that would necessarily arise. Fig. I shows the mountain of A'Cruach at Benmore with its bare rocky face before planting was done, and Fig. 2 shows it covered with forest trees. Both illustrations are from the Transactions of the Royal Scottish Arboricultural Society, and are here reproduced by the courtesy of the Society.

A. $\mathrm{H}$.

\section{WOOKEY HOLE.}

WOOKEY HOLE is situated in a narrow ravine on the south side of the Mendips, two miles from the cathedral city of Wells. Those familiar with the labours of the pioneers who discovered the presence of man in Pleistocene deposits of British caves need no introduction to this ravine in the Mendips, for the hyæna den, where Prof. Boyd Dawkins, the doyen of British "cave-hunters," commenced his labours fifty-five years ago, is situated on its eastern side, within stone-throw of the main series of caves which open on the ivy-covered crags at the northern or blind end of the ravine.

At the time when Prof. Boyd Dawkins (in partnership with the late Rev. T. Williamson) was commencing his early exploration of the hyæna den (I 859), Pengelly and Falconer were bringing their exploration of the cave at Brixham to a close and were in a position to prove that the earlier discoveries made by the Rev. J. MacEnery at Kent's cavern and by Schmerling in the caves along the Meuse were true-namely, that man had been a contemporary of extinct animals such as the mammoth and woolly rhinoceros. Prof. Boyd Dawkins's explorations in the hyæna den at Wookey Hole clinched the matter; man had been living in England in the Pleistocene period. It is also worthy of remark that at the very time Prof. Boyd Dawkins was at work at Wookey Hole, Lartet was exposing, in the strata and hearths of the cave at Aurignac, human bones mingled with the charred remains of extinct animals and certain types of human implements-now recognised as characteristic of a period of Pleistocene culture.

In $1887, \mathrm{Mr}$. Henry Balch, the author of the work now under review, one to which artist, engraver, printer, and bookbinder have given of their best, began to make further explorations in

1 "Wookev Hole: Its Caves and Cave Dwellers." Ry H. E. BalchPp. xiv +268 . (London: Humphrey Milford, Oxford University Press, rgr4.) Price 25 s. net. 
the hyæna den, and afterwards transferred his labours to the main caverns which open at the head of the Wookey Hole ravine. In the vestibule or passage leading to the first of the three great caverns (see Fig. I) he found a deposit on the floor amounting in thickness to nearly six feet. The main part of this work is an account of the exploration of this deposit. It is clear from the author's account that the vestibule or entrance had been used as a habitation by man during two periods. The more superficial or recent layers contained pottery and implements belonging to the period of the Roman occupation; the deeper strata were marked by objects belonging to a pre-Roman period-one which reaches back, in Mr. Balch's opinion, to ancient Bretons. He elaborates a tragic short story of a goat-herd to explain the discovery of part of a human skeleton, the skulls of two goats, an earthenware pot, a tethering stake, and a deposit of goat manure in the strata and recesses of the cave floor (see Fig. 2).

Mr. Balch suspects the cave-dwellers of cannibalism (I) because stray human bones were found in the strata of the cave, mixed with animal bones, and (2) because some early writers have alleged that the ancient British were cannibals. None of the bones showed the least mark of human workmanship-of knife or of saw; the fractures which Mr. Balch figures are those which may be seen in human bones dug from modern graves-fractures produced by the grave digger's spade. If

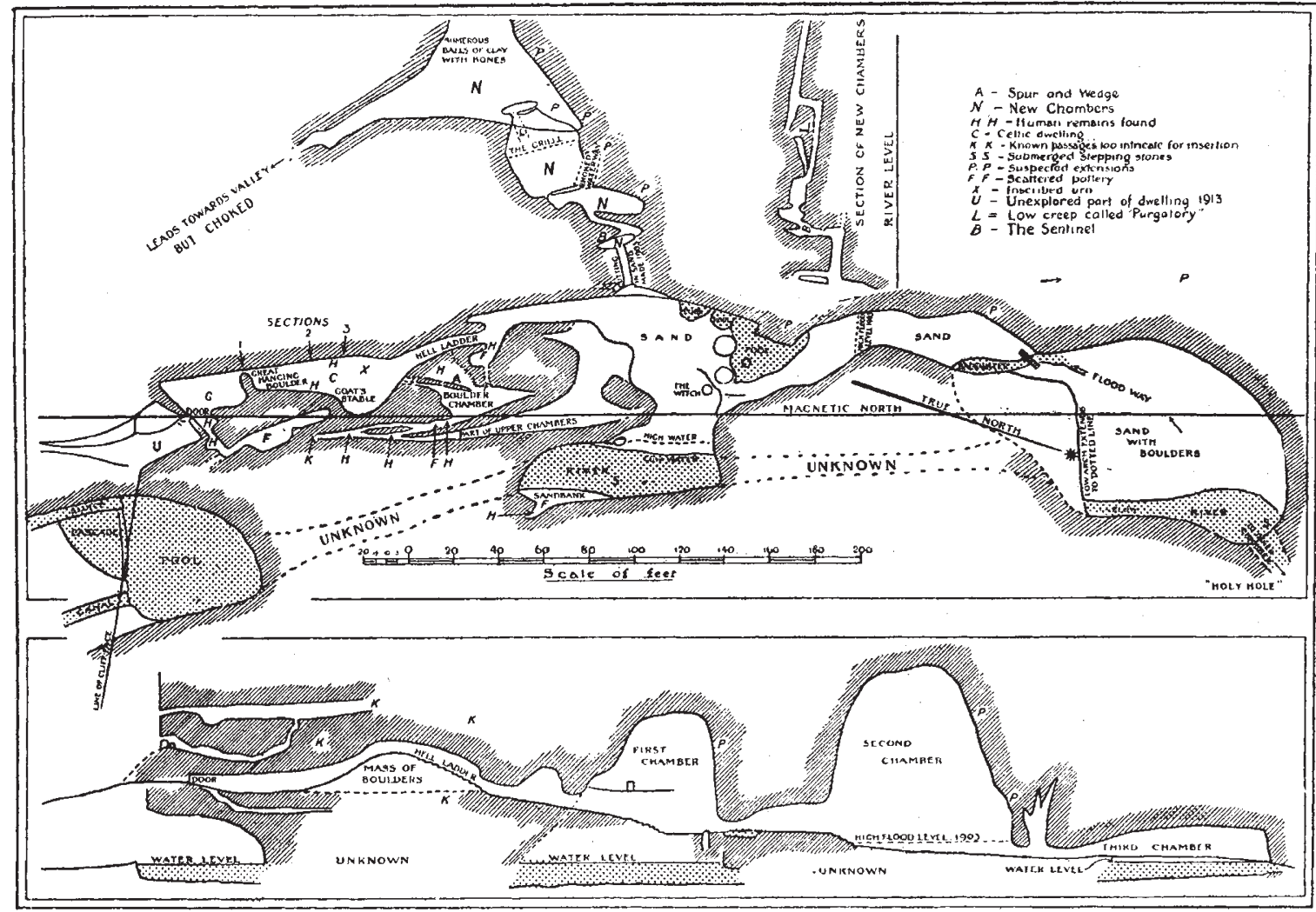

FIg. I--Wookey Hole Cavern. Plan and Section by H. E. Balch and R. D. R. Troup, igra. From "Wookey Hole: its Caves and Cave Dwellers."

about 400 B.C. The pottery, implements, ornaments, and objects of culture, found in the deeper strata are identical with those revealed by the investigations at Glastonbury. It is evident that the cave was used as a habitation when the neigh:bouring lake-village of Glastonbury was in existence.

Mr. Balch describes and figures in full detail all the traces left by these ancient pre-Roman inhabitants of Somerset. $\mathrm{He}$ has brought his imagination to bear on all the details and sought to reconstruct the home life of the cave-dwellers -ably seconded by the pencil and brush of $\mathrm{Mr}$. John Hassall. He pictures the arrival of these cave-dwellers from Brittany, in order to explain the similarity of their cave pottery to that of the human bones are found scattered in the floorstrata of a British cave there is no need to suspect our ancestors of cannibalism. Nothing is better known than that Neolithic people used caves as sepulchres. We know, too, that rabbits and all sorts of animals which frequent caves, scatter the bones of skeletons embedded in the floor. Mr. Balch himself discovered a small cave in the heights above the Wookey Hole ravine; he relates how the human remains on the floor of that cave had been dismembered and spread by the animals frequenting the cave. No; $\mathrm{Mr}$. Balch must bring more convincing evidence to convict the cave-dwellers of Wookey Hole of cannibalism.

Mr. Balch, with justice, dedicates his book to

NO. 2354 , VOL. 947 
Prof. Boyd Dawkins, who contributes an introductory chapter, in which he fights gallantly for opinions and conclusions put forward fifty years ago. In the opinion of the veteran geologist of Manchester we have not yet discovered a specimen of the people who lived in the caves of the Mendips during the Pleistocene period. The human skeleton discovered in Gough's cave at Cheddar he regards as an interment of the Neolithic periodwhereas those who have investigated the evidence relating to the antiquity of the Cheddar man have formed an entirely opposite opinion-namely, that he represents a race which inhabited Somerset during Pleistocene time. Through the kindness of Prof. Fawcett of Bristol the writer of this note had an opportunity of examining two human

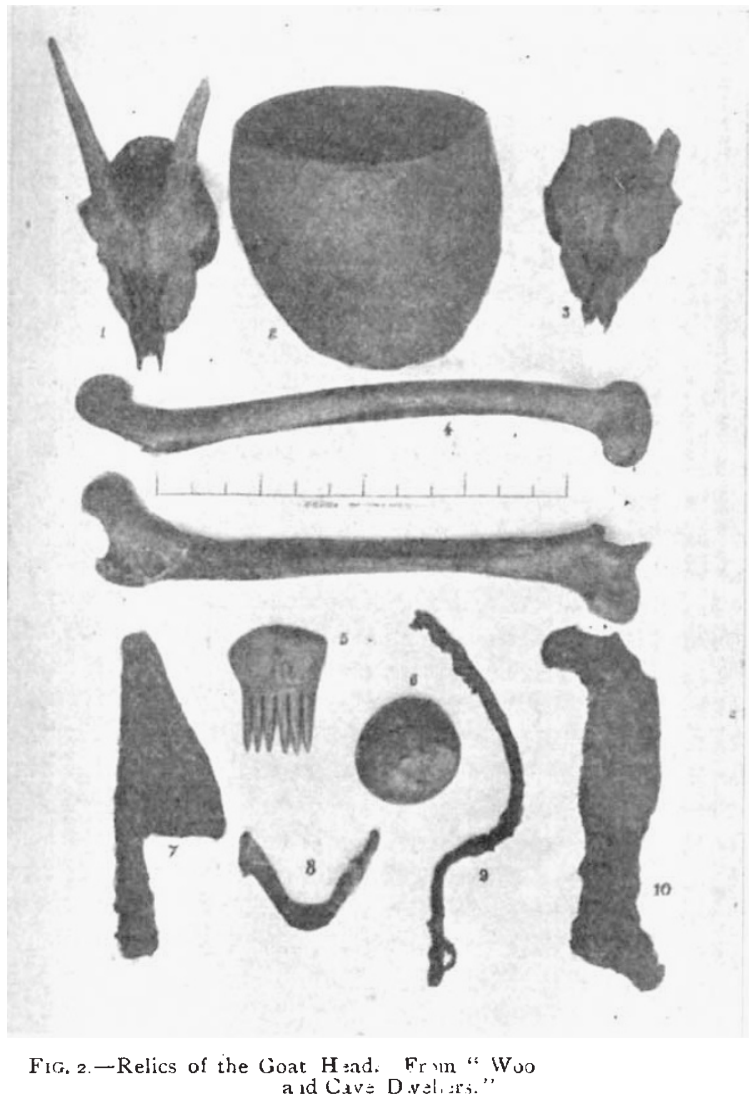

skulls dug from the cave earth beneath the stalagmite of one of the Mendip caves. All the circumstances attending their discovery show that they are Pleistocene in age. What is more to the point is that they are exactly of the same form and show the same characteristics as the Cheddar skull. More interesting still, those ancient cave men are apparently of the same race as the early. Neolithic people of England. Those who are following closely the progress of our knowledge of the ancient inhabitants of Britain expect much from the caves of the Mendips, and from hints dropped by Mr. Balch in this work, we have every reason to expect that these hopes will be realised.

A. KeITH.

\section{NOTES.}

Dr. C. S. Sherrington has been elected Fullerian professor of physiology at the Royal Institution for a term of three years, the appointment to date from January 13 , I9I5.

WE regret to see the announcement of the death, at eighty-nine years of age, of the Rev. Sir John F. Twisden, formerly professor of mathematics at the Staff College, and also for forty years one of the professional examiners in mechanics to the Department of Science and Art, and afterwards to the Board of Education.

IT is reported from Paris that Prof. A. Calmette, director of the Pasteur Institute at Lille, who resumed service at the beginning of the war in the capacity of Medical Inspector of Colonial Troops, is a prisoner at Munster, in Westphalia. Should any readers of NATURE have news of other men of science who are interned or prisoners on account of the war, perhaps they will send it to us for publication.

THE European war has unexpectedly checked scientific exploration in South America. Dr. W. C. Farabee, the leader of the University of Pennsylvania's expedition up the Amazon, has sent home word that he has had to cut short his journey owing to the fact that "the lack of funds, due to the uneasiness over the European war, made transportation difficult." The party had, however, already travelled about 4000 miles, and made some valuable anthropological collections.

THE eleventh award of the Reuben Harvey Memorial triennial prize will be made on July I next. The prize will be awarded to the writer of the best essay, on a subject to be selected by the candidate, showing original research in animal physiology or pathology, the essay to be illustrated by drawings or preparations. The competition is open' to all students of the various recognised schools of medicine in Dublin, and to graduates or licentiates of the medical licensing bodies in Ireland of not more than three years' standing. The essays must be sent on or before June I next to the registrar of the Royal College of Physicians of Ireland, Dublin.

THE next meeting of the American Association for the Advancement of Science and of the affiliated scientific societies will be held in Philadelphia, and will begin on December 28 . The retiring president, Dr. E. B. Wilson, of Columbia University, will introduce the president of the meeting, Dr. C. W. Eliot, of Harvard University, and will give the annual address on some aspects of progress in modern zoology. An interesting event of the meeting will be the first assembly of the newly established section of agriculture, which will meet on December 30 . The adaress of the vice-president of the section, Dr. L. H. Bailey, late director of the College of Agriculture at Cornell University, will deal with "The Place of Research and of Publicity in the Forthcoming Country Life Development." A symposium on the general subject of "The Field of Rural Economics" has also been arranged. 